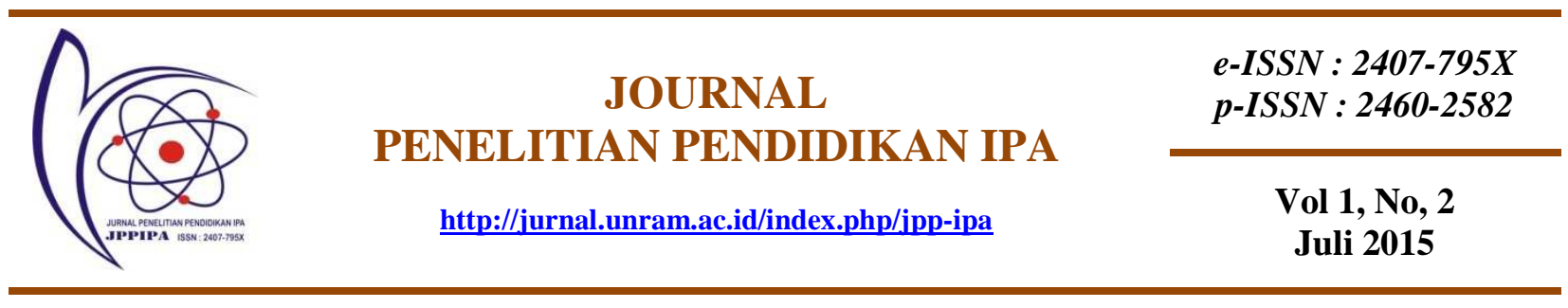

\title{
PENINGKATAN AKTIVITAS DAN HASIL BELAJAR MAHASISWA DENGAN MENERAPKAN METODE DISKUSI KELOMPOK PLENO PADA MATA KULIAH EVOLUSI DI STKIP PGRI SUMBAR
}

\author{
RUTH RIZE PAAS MEGAHATI ${ }^{1}$, MELIYA WATI ${ }^{2}$, ELZA SAFITRI ${ }^{3}$ \\ Program Studi Pendidikan Biologi STKIP PGRI Sumbar ${ }^{123}$ \\ biomolekuler@yahoo.com
}

\begin{abstract}
\begin{tabular}{ll}
\hline Key Words & Abstract \\
\hline Discussion, & Lack of understanding of concepts and facts in the Evolution subject leads to low
\end{tabular}
study group, activity and student learning achievement. That are caused students simply expect and pleno information from lectures who are still using regular discussion. The purpose of this discussion research is to improve the activity and student learning achievement at the Evolution course. Learning activities that are studied, among others asking, answering questions, the moderator, presenter on discussions, and taking note of the lecturer. This type of research is a class action research in the class that may have activity and low learning achievement. Learning achievement assessed is cognitive aspect only the cognitive. Increasing of activity and student learning achievement will be done by using the method of group learning plenary discussion. It a method in which all participants can be used to describe a particular topic or concept so the understanding of the participants are expected to be the same. Application of the method plenary discussion on the course of evolution can improve the activity and student learning achievement of Biology education students of STKIP PGRI of West Sumatra
\end{abstract}

\begin{tabular}{ll}
\hline Kata Kunci & Abstrak \\
\cline { 2 - 4 } $\begin{array}{l}\text { Diskusi, } \\
\text { belajar }\end{array}$ & Kurangnya pemahaman konsep dan fakta-fakta pada mata kuliah Evolusi \\
kelompok, & menyebabkan rendahnya aktivitas dan hasil belajar mahasiswa. Hal tersebut \\
diskusi pleno & kegabkan karena mahasiswa hanya mengharapkan informasi dari dosen dan \\
& ini adalah untuk meningkatkan aktivitas dan hasil belajar mahasiswa pada mata \\
& kuliah Evolusi. Aktivitas pembelajaran yang akan diteliti, antara lain bertanya, \\
& menjawab pertanyaan, menjadi moderator, penyaji pada kegiatan diskusi, dan \\
& mencatat keterangan dosen. Jenis penelitian adalah tindakan kelas pada kelas yang \\
& bermasalah atau mempunyai aktivitas dan hasil belajar yang rendah. Hasil belajar \\
& yang akan diukur adalah hasil belajar pada ranah kognitif. Peningkatan aktivitas \\
& dan hasil belajar mahasiswa dilakukan dengan menggunakan metode diskusi \\
& belajar kelompok pleno. merupakan metode diskusi kelompok yang dimana semua \\
& peserta dapat digunakan untuk menjelaskan topik atau konsep tertentu sehingga \\
& pemahaman peserta diskusi diharapkan akan sama. Penerapan metode diskusi \\
& pleno pada matakuliah evolusi dapat meningkatkan aktivitas dan hasil belajar \\
& mahasiswa pendidikan Biologi Sekolah Tinggi Keguruan dan Ilmu Pendidikan \\
& Persatuan Guru Republik Indonesia Sumatera Barat.
\end{tabular}




\section{PENDAHULUAN}

Evolusi merupakan salah satu mata kuliah wajib yang diikuti oleh setiap mahasiswa program studi pendidikan Biologi STKIP PGRI Sumbar pada semester enam. Mata kuliah evolusi mempunyai batasan dan ruang lingkup, seperti teori-teori evolusi menurut para ahli, prokontra teori evolusi, asal usul kehidupan, mekanisme evolusi, mekanisme spesiasi dan lain-lain. Mata kuliah ini bertujuan agar mahasiswa program studi pendidikan Biologi STKIP PGRI Sumbar mempunyai pengetahuan dalam konsep-konsep, fakta-fakta, dan mekanisme evolusi. Pada kenyataannya masih banyak mahasiswa yang tidak menguasai konsep-konsep, fakta-fakta, dan mekanisme evolusi sehingga hasil belajar mahasiswa pada matakuliah evolusi masih banyak yang rendah terlihat dari hasil tes yang dilakukan yaitu lebih dari $60 \%$ mahasiswa mendapat nilai C dan D. Bila dilihat aktivitas mahasiswa masih belum menunjukkan antusiasme yang besar dalam pembelajaran mata kuliah evolusi hal ini menyebabkan tidak teraktifkan potensi dan kemampuan mahasiswa secara maksimal, mahasiswa hanya sebagai pendengar akibatnya mahasiswa cenderung pasif dalam kegiatan pembelajaran dikelas.

Melihat kondisi tersebut peneliti terdorong mengkaji berbagai aspek yang berkaitan dengan pembelajaran. Aspek-aspek yang berkaitan dengan pembelajaran menunjukkan perlu adanya perbaikan pada teknik pembelajaran dan belajar yang selama ini dilakukan. Maka dari itu diperlukan adanya solusi yang tepat untuk perbaikan pembelajaran pada mata kuliah evolusi. Berdasarkan alasan tersebut dilakukan penelitian tindakan kelas guna memperbaiki proses pembelajaran.

Penelitian Tindakan Kelas (PTK) merupakan suatu penelitian yang dilakukan secara sistematis reflektif terhadap berbagai "aksi" atau tindakan yang dilakukan oleh dosen atau peneliti, mulai dari perencanaan sampai dengan penilaian terhadap tindakan nyata di dalam kelas yang berupa kegiatan belajar-mengajar untuk memperbaiki kondisi pembelajaran (Arikunto, 2006).

Penelitian tindakan kelas dapat dilakukan dengan mengaplikasikan suatu model pembelajaran yang dapat membuat siswa menjadi aktif dan kreatif. Pembelajaran aktif merupakan suatu pembelajaran yang mengajak mahasiswa untuk belajar secara aktif. Belajar aktif mendominasi aktivitas pembelajaran sehingga siswa secara aktif menggunakan potensi otak, dalam hal menemukan ide pokok, memecahkan persoalan, atau mengaplikasikan apa yang baru dipelajari. Dengan belajar aktif, mahasiswa akan turut serta dalam proses pembelajaran sehingga mahasiswa dapat menikmati suasana yang lebih menyenangkan (Zaini dkk, 2004).

Salah satu metode pembelajaran yang digunakan untuk meningkatkan aktivitas dan hasil belajar mahasiswa pada mata kuliah evolusi adalah menggunakan metode diskusi kelompok pleno yang merupakan metode diskusi kelompok yang dimana diantara semua peserta dapat digunakan untuk menjelaskan topik atau konsep tertentu sehingga pemahaman peserta diskusi diharapkan akan sama terhadap konsep - konsep pada mata kuliah evolusi. Metode diskusi kelompok adalah 
suatu bentuk kegiatan yang bercirikan suatu keterikatan pada suatu pokok masalah atau pertanyaan, dimana anggota anggota atau peserta diskusi itu secara jujur berusaha memperoleh kesimpulan setelah mendengarkan dan mempelajari, serta mempertimbangkan pendapat-pendapat yang dikemukakan dalam diskusi (Sukardi, 2008).

Bertitik tolak dari permasalahan aktivitas dan hasil belajar mahasiswa pada mata kuliah evolusi maka dilaksanakan penelitian tindakan kelas dengan judul "Peningkatan Aktivitas dan Hasil Belajar Mahasiswa Dengan Menerapkan Metode Diskusi Kelompok Pleno Pada Mata Kuliah Evolusi di STKIP PGRI Sumbar"

Penelitian ini bertujuan untuk meningkatkan Aktivitas dan hasil belajar mahasiswa menggunakan metode diskusi kelompok pleno pada mata kuliah Evolusi

\section{METODE PENELITIAN}

\section{Jenis Penelitian}

Jenis Penelitian yang dilaksanakan adalah Penelitian Tindakan Kelas (PTK) atau Classroom Action Research (CAR) yang dilakukan secara kolaboratif, artinya peneliti berkolaborasi atau bekerjasama dengan tim pada matakuliah anatomi fisiologi manusia. Dosen atau peneliti mendiskusikan permasalahan penelitian dan menentukan rencana tindakan. Penelitian juga dilakukan secara partisipatif, artinya peneliti dengan dibantu rekan satu tim matakuliah yang terlibat secara langsung dalam penelitian.

Penelitian dilakukan di STKIP PGRI Sumatera Barat pada mahasiswa semester enam tahun pelajaran 2014/2015 dengan matakuliah Anatomi Fisiologi Manusia angkatan 2011 Sesi A yang berjumlah 32 orang.

\section{Prosedur Penelitian}

Berdasarkan jenis penelitian yang dilaksanakan, maka prosedur dalam penelitian ini dikemas dalam bentuk siklus. Penelitian yang dilaksanakan ini terdiri atas dua siklus, siklus dihentikan setelah melihat peningkatan aktivitas belajar mahasiswa sesuai dengan indikator yang diinginkan dan meningkatnya tes kemampuan mahasiswa dalam hal ini pemahaman konsep dan kemampuan pemecahan masalah. Secara garis besar setiap siklus terdiri atas 4 tahap, yaitu: perencanaan, tindakan, pengamatan, dan refleksi.

1. Siklus I.

a. Tahap Perencanaan

Pada tahap perencanaan dosen menyiapkan materi yang akan diberikan pada mahasiswa sesuai dengan silabus yang digunakan. 
b. Tahap tindakan

Pada tahap tindakan ada beberapa kegiatan yang dilakukan, antara lain dosen membuka kegiatan perkuliahan, masing-masing kelompok menampilkan materi/presentasi kelompok sedangkan mahasiswa yang lain menanggapi kegiatan presentasi, dan dosen menutup kegiatan perkuliahan.

c. Tahap pengamatan

Pada tahap ini teman sejawat membantu mengamati kegiatan perkuliahan dengan mengisi lembar observasi kegiatan mahasiswa, yaitu: mengamati peningkatan aktivitas mahasiswa secara individu selama mengikuti proses perkuliahan. Adapun hal yang akan diamati adalah :

- Mengajukan pertanyaan

- Memperhatikan uraian dosen

- Mencatat keterangan (uraian) dosen

- Menanggapi pertanyaan teman

Hasil observasi akan diskusikan pada tahap renungan

d. Tahap Refleksi

Pada tahap ini semua data dikumpulkan mulai dari tindakan dan observasi baik data kuantitatif maupun data kualitatif lalu menganalisanya dan menarik kesimpulan, Selanjutnya dilakukan revisi atau perbaikan pada siklus kedua untuk menambah motivasi pada siswa.

Perubahan yang akan dilakukan pada siklus kedua adalah :

1. Memberi tugas baca

2. Memberi tugas mingguan berupa makalah

\section{Teknik Pengumpulan Data}

1. Lembar pengamatan aktivitas, digunakan untuk mengetahui aktivitas mahasiswa selama proses pembelajaran berlangsung.

2. Tes hasil belajar, digunakan untuk mendapatkan data yang diperlukan untuk melihat persentase pemahaman mahasiswa terhadap materi perkuliahan.

\section{Teknik Analisis Data}

1. Analisis pengamatan aktivitas mahasiswa

Analisis data aktivitas belajar mahasiswa digunakan rumus persentase (\%) yang dikemukakan Sudijono (2004: 43).

$$
P=\frac{\mathrm{f}}{N} \times 100
$$

Keterangan:

$\mathrm{P} \quad$ : persentase aktivitas

f : frekuensi tiap aktivitas

$\mathrm{N}$ : jumlah frekuensi aktivitas mahasiswa 
Menurut Dimyati dan Mudjiono (1999:125) kriteria tingkat keberhasilan aktivitas belajar mahasiswa adalah terlihat seperti tabel 1 .

Tabel 1. Kriteria Keberhasilan Aktivitas Belajar Mahasiswa

\begin{tabular}{llc}
\hline \multicolumn{1}{c}{ Kriteria } & \multicolumn{1}{c}{ Tingkat Keberhasilan } & Range Persentase \\
\hline Kurang baik & Tidak berhasil/ tidak efektif & $1-25$ \\
Cukup baik & Kurang berhasil/ kurang efektif & $26-50$ \\
Baik & Berhasil/ efektif & $51-75$ \\
Sangat baik & Sangat berhasil/ sangat efektif & $76-100$ \\
\hline
\end{tabular}

2. Analisis Hasil Belajar

Hasil belajar mahasiswa diambil dari hasil tugas dan tes akhir. Nilai yang diperoleh diolah dengan menggunakan rumus yang dikemukakan oleh Arikunto (2012: 312) dan dimodifikasi menjadi:

$$
N A=\frac{2 \mathrm{~T}+3 \mathrm{H}}{5}
$$

Keterangan:
NA : Nilai Akhir
NT : Nilai Tugas
$\mathrm{NH} \quad$ : Nilai Ulangan Harian

\section{HASIL DAN PEMBAHASAN}

\section{Hasil}

\section{Aktivitas Mahasiswa}

Aktivitas belajar Mahasiswa pendidikan biologi STKIP PGRI Sumbar angkatan 2011-A dengan menerapkan metode diskusi kelompok pleno pada matakuliah evolusi menunjukan peningkatan dari siklus I ke siklus II

\section{Hasil Penelitian siklus I}

1. Aktivitas Mahasiswa

Berdasarkan hasil pengamatan pada siklus I belum terjadi peningkatan aktivitas mahasiswa, yaitu pertemuan 1 aktivitas bertanya 25,81\% dengan jumlah mahasiswa bertanya 8 orang, sedangkan pada pertemuan 2 aktivitas bertanya 12,9\% dengan jumlah mahasiswa 4 orang. Begitupun aktivitas menjawab pertanyaan 19,35\% dengan jumlah mahasiswa 6 pada pertemuan 1, sedangkan $16,35 \%$ dengan jumlah mahaiswa 5 orang pada pertemuan 2. Jika dilihat dari rata-rata aktivitas mahasiswa bertanya pada pertemuan 1 dan pertemuan 2 adalah 19,35\%, sedangkan rata-rata aktivitas menjawab pertanyaan pertemuan 1 dan 2 adalah 17,74\% 
terjadi penurunan aktivitas dengan kategori sedikit sekali. Hal ini dapat tergambar dalam Tabel 1 berikut ini :

Tabel 1. Persentase Aktivitas Mahasiswa Pada Siklus I

\begin{tabular}{|c|c|c|c|c|c|c|c|}
\hline \multirow[t]{2}{*}{$\mathrm{NO}$} & \multirow[t]{2}{*}{ Aktivitas yang diamati } & \multicolumn{2}{|r|}{$\mathrm{P} 1$} & \multicolumn{2}{|c|}{$\mathrm{P} 2$} & Rata-rata & \multirow[t]{2}{*}{ Kategori } \\
\hline & & $\mathrm{f}$ & $\%$ & $\mathrm{f}$ & $\%$ & $\%$ & \\
\hline 1 & Moderator & 2 & 6,45 & 2 & 6,45 & 6,45 & Sedikit sekali \\
\hline 2 & Presenter & 2 & 6,45 & 4 & 12,9 & 9,67 & Sedikit sekali \\
\hline 3 & Bertanya & 8 & 25,81 & 4 & 12,9 & 19,35 & Sedikit sekali \\
\hline \multirow[t]{3}{*}{4} & Menjawab Pertanyaan & 6 & 19,35 & 5 & 16,13 & 17,74 & Sedikit sekali \\
\hline & Jumlah & & & & & 53,21 & \\
\hline & Rata-rata & & & & & 13,30 & Sedikit sekali \\
\hline
\end{tabular}

Keterangan : $\mathrm{P} 1=$ Pertemuan pertama, $\mathrm{P} 2=$ Pertemuan kedua, $\mathrm{f}=$ jumlah mahasiswa

\section{Siklus II}

1. Aktivitas Mahasiswa

Berdasarkan hasil pengamatan pada siklus II terjadi peningkatan aktivitas mahasiswa yaitu pertemuan 1 aktivitas mahasiswa bertanya 35,48\% dengan jumlah mahasiswa 11 orang, sedangkan pertemuan 2 aktivitas mahasiswa bertanya 45,16\% dengan jumlah mahasiswa 14 orang. Jika dilihat dari rata-rata aktivitas bertanya pada pertemuan 1 dan 2 adalah 40,32\%, sedangkan rata-rata aktivitas mahasiswa menjawab pertanyaan pada pertemuan 1 dan 2 adalah $35,48 \%$ melihat dari perbandingan dari dua aktivitas yang diamati maka masih dengan kategori sedikit. Hal ini dapat pada tabel 2 dan tergambar pada gambar 2 berikut ini.

Tabel 2. Persentase Aktivitas Mahasiswa Pada Siklus II

\begin{tabular}{llllllll}
\hline \multirow{2}{*}{ NO } & \multirow{2}{*}{ Aktivitas yang diamati } & \multicolumn{2}{c}{$\mathrm{P} 1$} & & \multirow{2}{*}{$\mathrm{P} 2$} & $\begin{array}{l}\text { Rata-rata } \\
\text { Aktivitas }\end{array}$ & \multirow{2}{*}{ Kategori } \\
\cline { 3 - 8 } & & $\mathrm{F}$ & $\%$ & $\mathrm{~F}$ & $\%$ & $\%$ & \\
\hline 1 & Moderator & 2 & 6,45 & 2 & 6,45 & 6,45 & Sedikit sekali \\
2 & Presenter & 2 & 6,45 & 2 & 6,45 & 6,45 & Sedikit sekali \\
3 & Bertanya & 11 & 35,48 & 14 & 45,16 & 40,32 & sedikit \\
4 & Menjawab Pertanyaan & 8 & 25,8 & 14 & 45,16 & 35,48 & sedikit \\
& Jumlah & & & & & 88,7 & \\
& Rata-rata & & & & 22,17 & Sedikit sekali \\
\hline
\end{tabular}

Keterangan : $\mathrm{P} 1=$ Pertemuan pertama, $\mathrm{P} 2=$ Pertemuan kedua, $\mathrm{f}=$ jumlah mahasiswa 


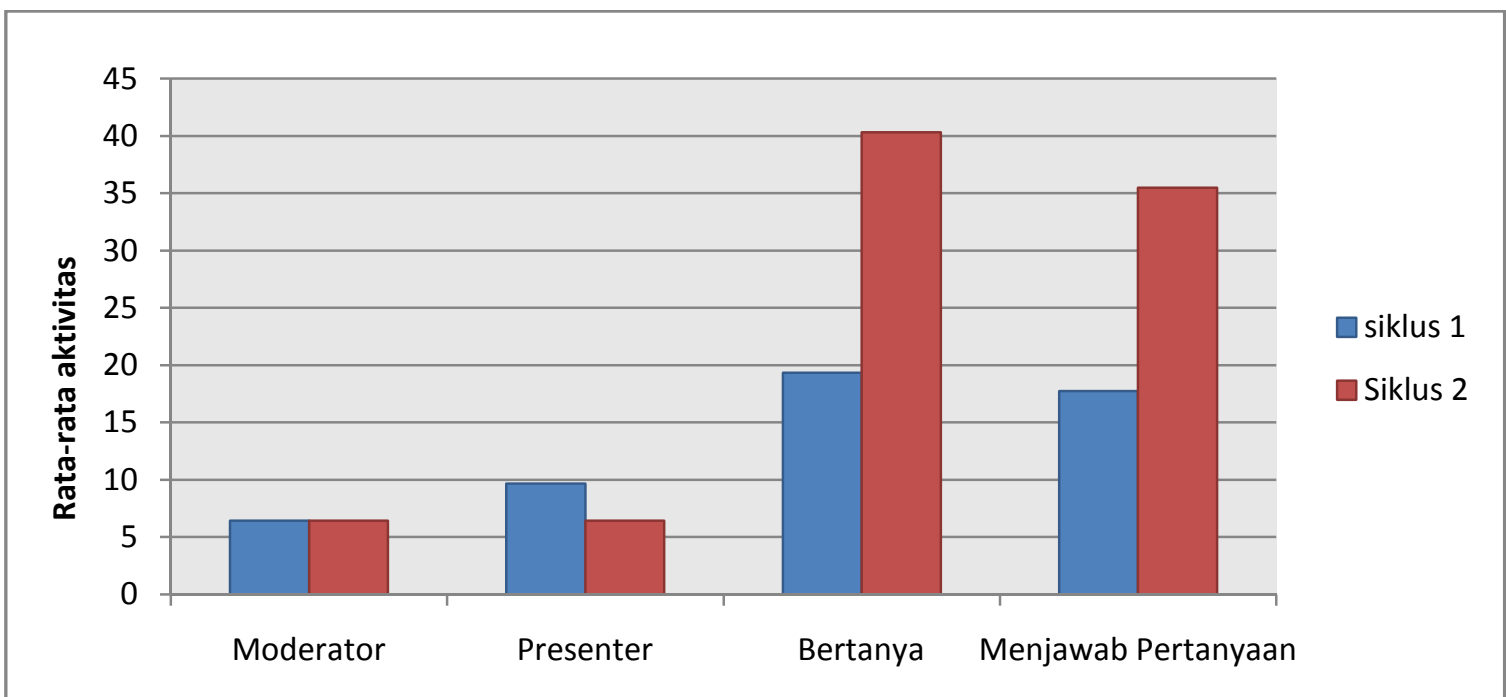

Gambar 1. Aktivitas pembelajaran mata kuliah evolusi mahasiswa SESI A angkatan 2011 STKIP PGRI Sumbar

\section{Hasil Belajar Mahasiswa}

Hasil belajar mahasiswa pada mata kuliah evolusi dengan menggunakan metode diskusi pleno terjadi peningkatan hal ini disebabkan karena mahasiwa sudah berani bertanya dan menjawab pertanyaan, hal in dapat dilihat dari nilai rata-rata kelas pada siklus I 61,41\% dengan ketuntasan belajar 21, $86 \%$ sedangkan pada siklus II rata-rata kelas 74,06\% dengan ketuntasan belajar 78,13\%. Peningkatan hasil belajar dapat dilihat dari Tabel 3 dan Gambar 2.

Tabel 3. Rata Nilai Hasil Belajar Mahasiswa Pada Siklus I dan Siklus II

\begin{tabular}{llcc}
\hline No & Hasil ulangan & \multicolumn{2}{c}{ Ulangan harian } \\
\hline & & Siklus I & Siklus II \\
1 & Nilai Rata-rata kelas & 61,41 & 74,06 \\
2 & Ketuntasan Belajar & $21,86 \%$ & $78,13 \%$ \\
\hline
\end{tabular}

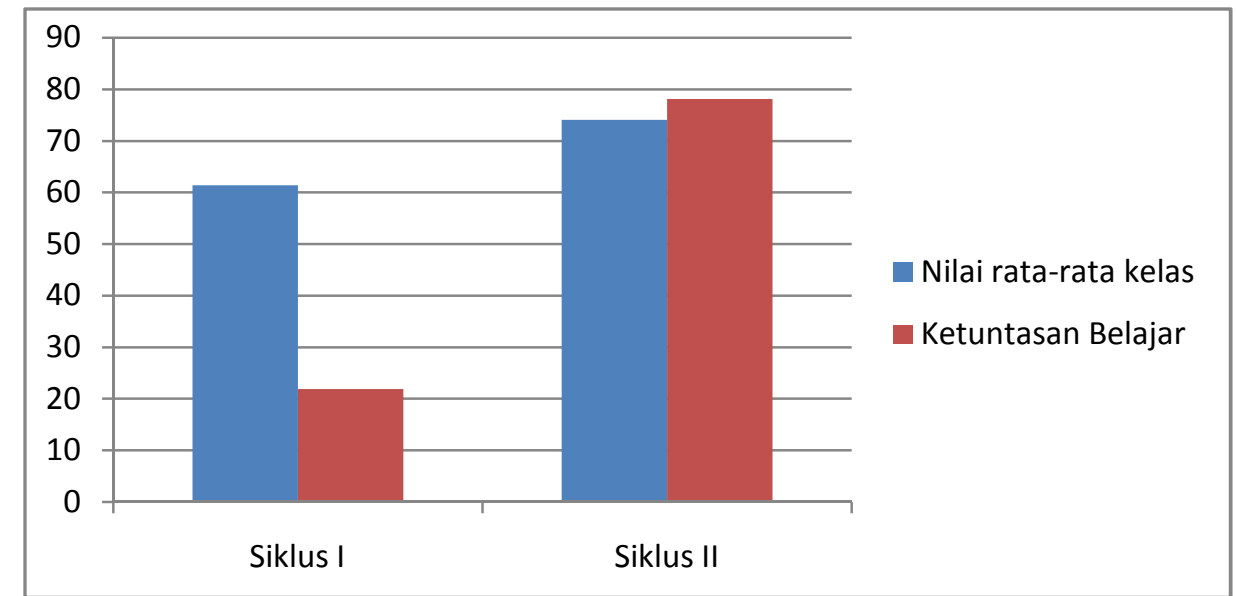

Gambar 2. Nilai Rata-Rata Dan Ketuntasan Hasil Belajar Mahasiswa SESI A angkatan 2011 STKIP PGRI Sumbar pada Siklus I dan Siklus II 


\section{Pembahasan}

\section{Aktivitas Mahasiswa}

Penyelenggaraan proses pembelajaran merupakan bagian dari tugas seorang dosen, idealnya dalam proses pembelajaran harus terjalin hubungan dan komunikasi yang baik antara dosen dengan mahasiswa dan mahasiswa dengan mahasiswa. Keaktifan mahasiswa diharapkan terlihat secara nyata di dalam proses pembelajaran baik secara perorangan ataupun kelompok. Hal ini bertujuan agar proses pembelajaran dan penguasaan materi oleh mahasiswa terserap dengan baik sehingga dapat meningkatkan kemampuan aktivitas dan hasil belajar mahasiswa. Menurut Hamalik (2004: 170) di dalam diri siswa terdapat prinsip aktif, keinginan untuk berbuat dan bekerja sendiri, prinsip inilah yang mengendalikan tingkah laku siswa.

Aktivitas dan hasil belajar yang rendah merupakan salah satu permasalahan yang ditemukan pada kelas yang diteliti. Sebelum menerapkan tindakan dosen selalu menggunakan model pembelajaran biasa (konvensional) yang tidak bervariasi misalnya metode ceramah, metode diskusi dan latihan. Dalam pembelajaran biasa (metode ceramah) dosen cenderung lebih aktif sebagai sumber informasi bagi mahasiswa dan mahasiswa cenderung pasif dalam menerima pelajaran. Dosen lebih banyak berbicara dalam hal menerangkan materi pelajaran dan mahasiswa hanya menerima materi pelajaran dan menghafalnya. Menurut Roestiyah (2001: 15) kelemahan teknik ceramah adalah tidak mampu mengontrol sejauh mana siswa telah memahami uraiannya. Ternyata model pembelajaran seperti ini dapat menyebabkan sebagian besar mahasiswa menjadi bersifat pasif, kurang kreativitas, enggan mengeluarkan pendapat dan merasa semuanya sudah cukup diperoleh dari penjelasan dosen. Hal ini sangat berpengaruh terhadap hasil belajar yang yang mereka peroleh.

Berdasarkan hasil penelitian pembelajaran dengan menggunakan metode diskusi pleno, dapat meningkatkan aktivitas dan hasil belajar mahasiswa, karena sebelum proses pembelajaran mahasiswa diberi tugas untuk membaca materi yang akan dibahas di dalam kelasl dan tugas mingguan berupa makalah, sehingga mahasiswa lebih memahami materi dan akan berperan aktif dalam diskusi. Dengan adanya tugas membaca dan makalah, peserta dapat digunakan untuk menjelaskan topik atau konsep tertentu sehingga pemahaman peserta diskusi diharapkan akan sama, yang sebelumnya sudah dibahas dalam diskusi kelompok kecil.

Menurut Sukardi (2008), metode diskusi kelompok adalah suatu bentuk kegiatan yang mencirikan suatu keterikatan pada suatu pokok masalah atau pertanyaan dimana anggota-anggota atau peserta diskusi itu secara jujur berusaha memperoleh kesimpulan setelah mendengarkan dan mempelajari serta mempertimbangkan pendapat-pendapat yang dikemukakan dalam diskusi.

Dari hasil penelitian diperoleh bahwa aktivitas mahasiswa bertanya pada siklus I masih dalam kategori sedikit sekali dengan persentase $19,35 \%$ dan mengalami peningkatan pada siklus II 
dengan persentase $40,32 \%$ dengan kategori sedikit. Peningkatan ini terjadi karena pertanyaan yang disampaikan dosen maupun peserta diskusi merangsang mahasiswa untuk lebih memahami materi pembelajaran. Hal ini sesuai dengan yang dikemukakan oleh Nurhadi (2004: 46) bahwa kegiatan bertanya sangat berguna dalam pembelajaran yang produktif. Sedangkan menurut Lufri (2007: 70) bahwa dengan bertanya akan merangsang anak didik aktif berfikir dan merangsang mereka belajar dengan teman-temannya atau dapat mengembangkan keterampilan kognitif tingkat tinggi anak didik.

Aktivitas mahasiswa menjawab pertanyaan mengalami peningkatan, yang mana pada siklus I masih dalam kategori sedikit sekali dengan persentase $17,74 \%$ sedangkan pada siklus II kategori sedikit dengan persentase $35,48 \%$. Peningkatan ini terjadi karena semua anggota kelompok penyaji dapat menjawab pertanyaan. Kelompok penyaji boleh meminta bantuan kepada peserta bukan kelompoknya, untuk membantu menjawab pertanyaan. Seperti dikemukakan (Nurhadi, 2004:46) memberikan kepada mahasiswa waktu untuk berpikir dan merespon serta saling bantu satu sama lain.

\section{Hasil Belajar}

Peningkatan aktivitas mahasiswa dengan menggunakan metode diskusi pleno ini memberi pengaruh terhadap peningkatan hasil belajar mahasiswa. Dari hasil penelitian yang diperoleh terlihat terjadinya peningkatan hasil belajar siswa. Setelah tindakan pada siklus I dilaksanakan persentase ketuntasan belajar $21,86 \%$ dan meningkat menjadi $78,13 \%$ pada siklus II. Terjadi peningkatan ini disebabkan karena adanya aktivitas dan interaksi diantara mahasiswa untuk saling bekerjasama atau saling membantu dalam menguasai materi pelajaran, guna mencapai hasil belajar yang maksimal.

Sebagaimana dikemukakan dalam Teori Piaget setiap individu mengalami tingkat-tingkat perkembangan intelektual sebagai berikut: 1) Sensori motor 0 sampai 2 tahun, 2) Pra operasional 2 sampai 7 tahun, 3) Operasional konkret 7 sampai 11 tahun, 4) Operasional formal 11 tahun ke atas. Dalam hubungannya dengan pembelajaran, teori ini mengacu kepada kegiatan pembelajaran yang harus melibatkan partisipasi peserta didik. Sehingga menurut teori ini pengetahuan tidak hanya sekedar dipindahkan secara verbal tetapi harus dikonstruksi dan direkonstruksi peserta didik. Sebagai realisasi teori ini, maka dalam kegiatan pembelajaran peserta didik haruslah bersifat aktif.

Hal ini sejalan dengan pendapat Budiningsih (2005:58) bahwa kegiatan belajar merupakan suatu proses pembentukan pengetahuan yang dilakukan oleh mahasiswa, dimana mahasiswa harus aktif melakukan kegiatan, aktif berpikir, menyusun konsep dan memberikan makna tentang hal-hal yang dipelajari. Peningkatan yang terjadi pada hasil belajar menurut Slameto (2003:65) salah satunya dipengaruhi oleh faktor pendekatan belajar yang meliputi strategi dan metode yang digunakan untuk melakukan kegiatan pembelajaran. Dengan demikian pembelajaran metode 
diskusi pleno dapat meningkatkan pemahaman siswa, aktivitas siswa bertambah, mahasiswa mampu berkomunikasi antar sesama teman, menumbuhkan rasa kebersamaan, antusias dan semangat belajar yang tinggi sehingga hasil belajar juga semakin tinggi.

\section{PENUTUP}

\section{Kesimpulan}

Setelah dilakukan penelitian tindakan kelas pada siklus I dan siklus II, hasil dari observasi dan hasil refleksi dapat disimpulkan sebagai berikut :

1. Telah terjadi peningkatan aktivitas belajar mahasiswa SESI A angkatan 2011 STKIP PGRI Sumbar pada mata kuliah evolusi akibat penerapan metode diskusi pleno. Perbandingan aktivitas pada siklus I dengan mengamati 4 aktivitas dengan kategori sedikit sekali, sedangkan pada siklus II ada 2 aktivitas dengan kategori sedikit yaitu aktivitas bertanya dan menjawab pertanyaan. Pada akhir siklus terjadi peningkatan walaupun tidak semua aktivitas yang meningkat.

2. Telah terjadi peningkatan hasil belajar mahasiswa kelas SESI A angkatan 2011 STKIP PGRI Sumbar pada mata kuliah evolusi akibat penerapan metode diskusi pleno. Perbandingan hasil belajar pada siklus I persentase mahasiswa yang mencapai ketuntasan belajar sebesar 21,86 \% sedangkan pada siklus II persentase mahasiswa yang mencapai ketuntasan sebesar 78,13\% dengan selisih perbandingan $56.27 \%$. Jika dilihat secara keseluruhan telah terjadi peningkatan hasil belajar pada siklus II hal ini sudah mencapai target yang telah ditetapkan.

\section{Saran}

Peneliti menyarankan agar tetap melakukan inovasi, variasi dalam pembelajaran sebagai upaya dalam meningkatkan aktivitas dan hasil belajar mahasiswa pada mata kuliah evolusi dan mata kuliah lainnya 


\section{DAFTAR PUSTAKA}

Anas, Sudijono. 2004. Pengantar Statistik Pendidikan, Jakarta : PT. Raja Grafindo Persada.

Arikunto, S. 2009. Dasar-dasar Evaluasi Pendidikan. Bumi Aksara: Jakarta.

Budiningsih, C. Asri. 2005. Belajar dan Pembelajaran. Jakarta: Rineka Cipta

Dimyati , Mudjiono. 1999. Belajar dan Pembelajaran. Jakart: PT. Rineka Cipta.

Hamalik, O. 2002. Model-model Pengembangan Kurikulum. UPI: Bandung.

Hamalik, O.. 2004. Metode Belajar dan Kesulitan Belajar Mengajar. Bandung : Tarsito

Lufri. 2007. Strategi Pembelajaran Biologi. Padang: UNP Press

Nurhadi dkk. 2004. Pembelajaran Kontekstual (Contextual Teaching and Learning/CTL) dan Penerapan dalam KBK. Malang. UNM

Roestiyah, 2001. Strategi Belajar Mengajar. Jakarta : Rineka Cipta

Slameto. 2003. Belajar dan Faktor-faktor yang mempengaruhinya. Jakarta: Rieneka Cipta.

Sukardi. 2008. Evaluasi Pendidikan Prinsip dan Operasioanal. Bumi Aksara: Jakarta.

Zaini, Hisyam, dkk., 2004, Strategi Pembelajaran Aktif, Yogyakarta: Pustaka Insan Madani. 